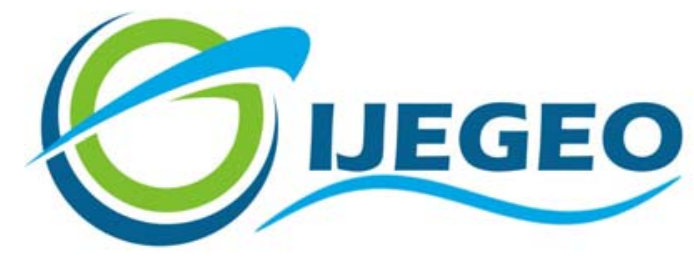

International Journal of Environment and Geoinformatics (IJEGEO) is an international, multidisciplinary, peer reviewed and certified open access journal.

\title{
Spatio-Temporal Urban Expansion Analysıs in a Growing City of Oyo Town ,Oyo State, Nigeria Using Remote Sensing And Geographic Information System (GIS) Tools
}

\section{Jimoh Rafiu. A, Afonja Yusuf .O, Albert Christopher.O. and Amoo .NB}

\section{Editors}

Prof. Dr. Cem Gazioğlu, Prof. Dr. Dursun Zafer Şeker, Prof. Dr. Ayşegül Tanık, Prof. Dr. Şinasi Kaya, Assist. Prof. Dr. Volkan Demir

\section{Scientific Committee (2018)}

Dr. Abdullah Aksu, Prof. Dr. Bedri Alpar, Prof. Dr. Gülşen Altuğ, Prof. Dr. Lale Balas, Prof. Dr. Can Balas, Prof. Dr. Levent Bat, Prof. Dr. Bülent Bayram, Prof. Dr. Nuray Çağlar, Prof. Dr. Jadunandan Dash, Prof. Dr. A. Evren Erginal, Dr. Dieter Fritsch, Dr. Amin Gharehbaghi, Assoc. Prof. Dr. Tolga Görüm, Prof. Dr. Melike Gürel, Dr. Hakan Kaya, Prof. Dr. Fatmagül Kılıç, Assoc. Prof. Dr. Maged Marghany, Prof. Dr. Nebiye Musaoğlu, Prof. Dr. Masafumi Nakagawa, Prof. Dr. Haluk Özener, Prof. Dr. Erol Sarı, Prof. Dr. Elif Sertel, Prof. Dr. Nüket Sivri, Assoc. Prof. Dr. Füsun Balık Şanlı, Prof. Dr. Uğur Şanlı, Assoc. Prof. Dr. Hasan Özdemir, Prof. Dr. Taşkın Kavzoğlu, Msc. Mustafa Üstüner, Assoc. Prof. Dr. Oral Yağcı, Prof. Dr. Seyfettin Taş, Assoc. Prof. Dr. Ömer Suat Taşkın, Assoc. Prof. Dr. İ. Noyan Yılmaz, Dr. Baki Yokeş, Dr. Sibel Zeki 


\title{
Spatio-Temporal Urban Expansion Analysıs in a Growing City of Oyo Town ,Oyo State, Nigeria Using Remote Sensing And Geographic Information System (GIS) Tools
}

\author{
Jimoh Rafiu.A ${ }^{1^{*}}$, Afonja Yusuf .0 ${ }^{2}$, Albert Christopher. ${ }^{3}$, Amoo . N.B. ${ }^{4}$ \\ ${ }^{1}$ Geomodeling and Geoexplore Consultants Limited, P.O. Box 302, Ikorodu, LagosState, Nigeria. \\ ${ }^{2}$ Department of Surveying and Geoinformatics, Federal School of Surveying, P.M.B 1024, Oyo, Oyo State, Nigeria \\ ${ }^{3}$ Copine,National Space Research and Development Agency(NASRDA),Federal Ministry of Science and Technology,P.M.B \\ 022,Ile Ife, Osun State, Nigeria \\ ${ }^{4}$ Department of Surveying and Geoinformatics, Federal Polytechnic Ede, P.M.B 231, Ede, Osun State, Nigeria
}

\begin{abstract}
The assessment of the land use / land cover expansion that occurred in the area over a period of thirty years is the utmost priority of this research work. Multi temporal Landsat satellite imageries TM 1984, 1990 and ETM+ 2002, 2014 from the United States Geological Survey (USGS) website were used as the primary dataset. Area of interest was clipped in ArcGIS 9.3 environment, image enhancement and image classification were adequately done using ENVI 4.5 remote sensing software. Using supervised classification algorithm, the images were classified into bare soil, built-up area, vegetation, water body and wetland; these were then used to carry out change detection analysis or time series analysis. Results obtained from the analysis of built-up area dynamics for the past three decades revealed that the town has been undergoing urban expansion processes. The expansion was prolonged both from urban center to adjoining non-built-up areas in all directions. The total built up area in the town has expanded from $28.04 \mathrm{sq} / \mathrm{km}$ in 1984 to $49.51 \mathrm{sq} / \mathrm{km}$ in 2014 at an average expansion rate of 0.7, 0.4 and 0.9 per annum during $1984-1990,1990-2002$ and $2002-2014$ study periods respectively. The study period from $2002-2014$ was the time at which the town experienced the highest urban expansion. The analysis of spatial trend revealed that the urban landscape has experienced a process of sprawling and fragmented development pattern particularly in the fringe areas while the town center underwent infill and edge expansion development processes. The fringe areas show scattered expansion pattern. Quantifying urban expansion patterns and development processes of the past trends can help better understand the dynamics of built up area and guide sustainable urban development planning of the future urban growth.
\end{abstract}

Keywords: Multi temporal Landsat satellite imageries, supervised classification algorithm, Change detection analyses, Remote Sensing, GIS

\section{Introduction}

Monitoring growth and change brought by metropolitan development is of critical concern to those who study metropolitan dynamics or urban climatology/meteorology and those who must manage resources and provide services in these rapidly changing environments. Urbanization has been a universal and important social and economic phenomenon taking place all around the world. This process with no sign of slowing down, could be the most powerful and visible anthropogenic force that has brought about fundamental changes in land cover and landscape pattern around the globe. Rapid urbanization and urban expansion especially in the developing world is continuing to be one of the crucial issues of global change in the 21 st century affecting the physical dimensions cities (Dihkan et al., 2017). In the past few decades, urbanization and urban growth have drastically accelerated in many developing countries. According to United Nations, in 2011, 3.6 billion of the world's population $(52 \%)$ was urban dwellers. Universally, the level of urbanization is expected to rise to $67 \%$ in 2050 . In the less developed regions, the proportion of urban will rise from $47 \%$ in 2011 to $64 \%$ in 2050 . In Africa alone the urban population is expected to 
triple from 414 million in 2011 to 1.2 million 2050 .

In most countries, urbanization is recognized as a crucial phenomenon of economic growth and social change as it offers increased opportunities for employment, specialization, production and goods and services. This has initiated a large number of people to migrate from rural to urban area. As a result, cities are growing faster than ever (in physical dimensions), being a huge center for residence, industry, trade and goods and services. However, this growth also triggers numerous problems. Environmental pollution and degradation, increased environmental hazards such as flooding, population explosion, insufficient sanitation and water supply, transport problems, poor housing conditions, rising cost of living and wealth inequality, and increase in crime rate, and loss of fertile agricultural and wetlands are some of the most prominent negative effects of rapid urbanization and urban growth (UNHABITAT, 2012, Burak et al., 2004). The urban expansion process in Oyo town is accompanied by the proliferation of unplanned settlements with inadequate services and infrastructure as well as environmentally sanitation problems. Moreover, following the growing demand for empirical data and systematic analysis of urban growth processes and patterns, there is an increasing curiosity on the development of quantitative methods of urban analysis. There are three major types of urban growth as infill, expansion, and outlying. Infill, development is a new development within remaining open space in already existing built up areas whereas expansion or sometimes called urban extension or edge expansion is a non-infill development extending the urban footprint in an outward direction sometimes called urban fringe development outlying or leap-frog development is a change from nondeveloped to developed land cover occurring beyond existing developed areas. Leap-frog development is also referred to as urban sprawl as the expansion of urban area is in a way that demands the extension of public facilities. Traditionally, visual interpretations of highresolution aerial photographs were used to acquire comprehensive information for mapping of urban areas. This mapping technique is expensive and time consuming for the estimation of urban expansion. However, with the gradual advancement and availability of high temporal and spatial resolution remote sensing imagery, the possibilities of monitoring urban problems with a better accuracy have become more promising. Hence, accurate mapping of urban environments and monitoring urban expansion is becoming increasingly important at the global level (Guidon and Zhang, 2009). Nowadays, there are many remote sensing satellite systems such as Landsat (TM \& ETM+), ASTER, IKONOS, Geo Eye, Quick bird, Rapid Eye, Worldview providing from medium to high and very high resolution imagery. It is also believed that remote sensing imagery is a powerful tool for acquiring data to analyze and map spatiotemporal land use change and urban expansion process at different spatial scale (J. Huang et al, 2007; Yang and Lo 2002). Particularly, in developing countries, remote sensing may provide fundamental observations of urban growth and environmental conditions that are not available from other sources (Miller and Small, 2003). Yet, it lacks the ability to fully describe the underlying urban processes (Herold et al, 2005).

\section{Study Area}

Oyo is one of the major towns in Oyo State, Nigeria, that is next in the hierarchy to the state capital - Ibadan. The history of Oyo dates back to the 12th century when it was the headquarters of Oyo kingdom. The town lies approximately between the longitude $3054^{\prime} \mathrm{E}$ to $3059^{\prime} \mathrm{E}$ and latitude $7047^{\prime} \mathrm{N}$ to $7055^{\prime} \mathrm{N}$ in the south western part of Nigeria. There are three local government areas in Oyo town: Atiba, Oyo West and Oyo East Local Governments as shown in Fig.1 (a, b and c).With the 2006 National Population Census, Oyo East Local Government has a population of 124,095, Oyo West Local Government with population figure of 136,457 and Atiba Local Government has a population of 168,246 . Oyo town is blessed with many educational institutions at all levels ranging from preprimary schools to tertiary institutions. The prominent ones among the institutions are the Federal Government Girls College, Government Technical College, Emmanuel Alayande College of Education, Federal 
College of Education (Special), Federal School of Surveying, Ajayi Crowther University and the Proposed Atiba University.

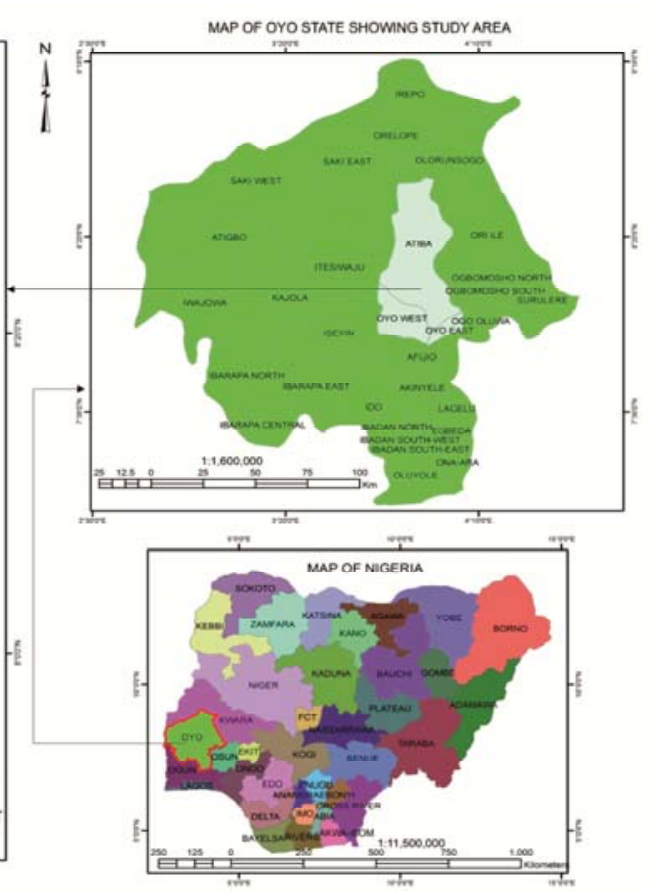

Fig 1. Map showing the study Area

\section{Materials and Methods}

Important data required to carry out the research including primary and secondary data are collected during field work. These includes interviewing local experts on the issues of urban expansion during field work, collecting ground truth data, visiting important places of the study area, new development sites to have the general impression of the study area. The methodology adopted for this research work involves remote sensing image classification techniques as well as spatio-temporal analysis. Four multi-temporal sets of Landsat images (TM 1984 and 1990, ETM+ 2002 and 2014) covering the entire study area are used to produce the land cover map by using the maximum likelihood classification algorithm in ENVI 4.5 as seen in Figure 2.Post-classification comparison is used to produce expansion/change map, where the classified images are overlaid on top of each other in (Osgouei, and Kaya, 2017) ArcGIS 9.3 using different spatial analyst tools. The spatial extent and rate of urban expansion

\section{Results and Discussion}

The results of the data analyzed were presented in the form of maps, tables and charts.

\section{Image Classification Results}

The classification of the multi-temporal satellite images into built up, vegetation, bare soil, wetland and water body for the four different time periods of 1984, 1990, 2002 and 2014 has resulted in a highly simplified and abstracted representation of the study area as shown in Figures 3 and 4 respectively. The results presented in Table 2 for each classes show that the total built -up area has grown from $14.453949 \mathrm{~km} 2$ in 1984 to $42.484771 \mathrm{~km} 2$ in 1990 , to $64.071 \mathrm{~km} 2$ in 2002 and then to $113.5818 \mathrm{~km} 2$ in 2014 respectively. This is due to the urbanization of the town. The Figure 5 shows changes in all different classes across the years which are representation in pie chart and Histogram statistically. 

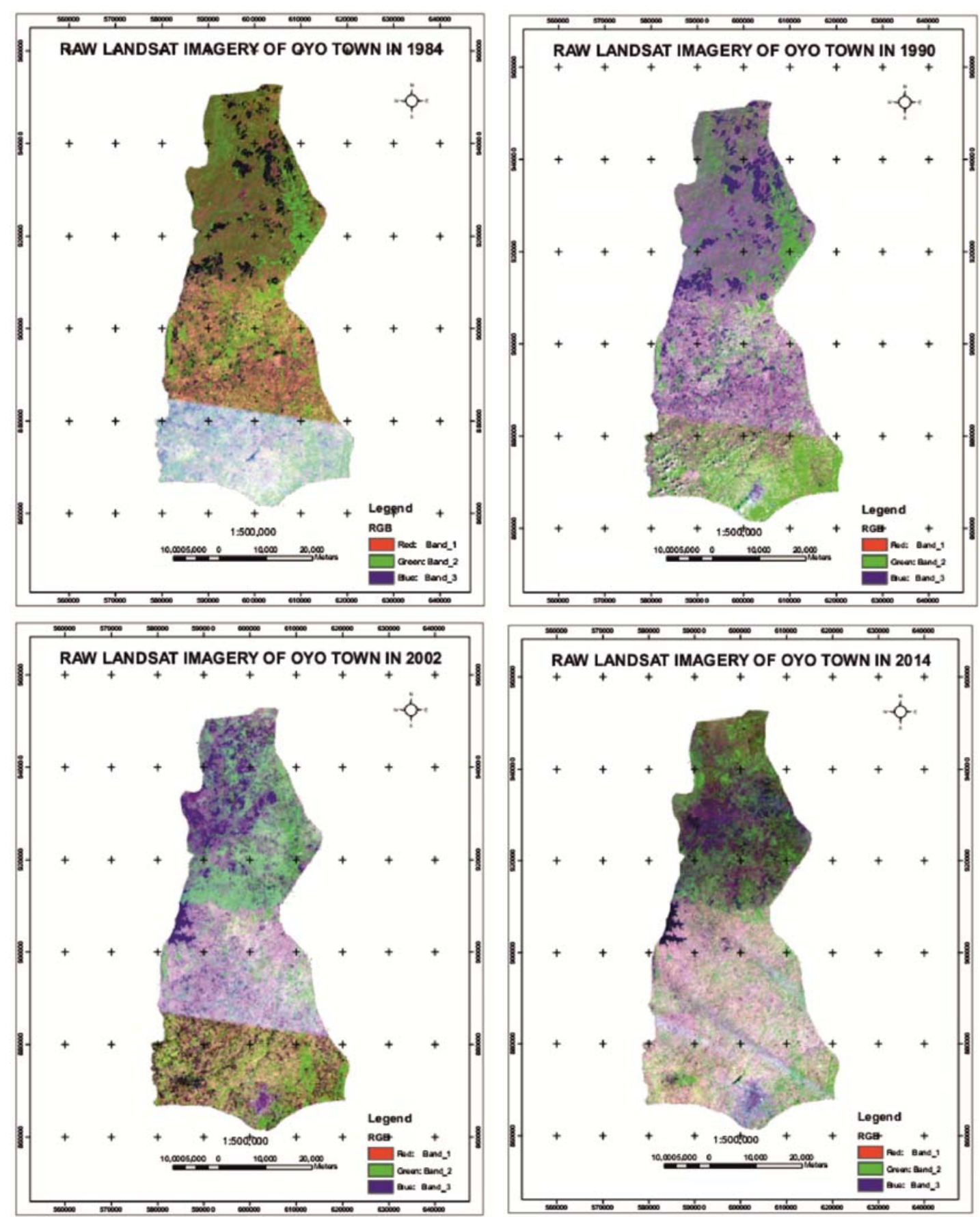

Fig 2. Landsat Imageries of Oyo Town for 1984, 1990, 2002 and 2014 
Table 1: List of Satellite Images (raster data) collected for the study area

\begin{tabular}{|l|l|l|l|l|}
\hline $\begin{array}{l}\text { Satellite } \\
\text { data }\end{array}$ & $\begin{array}{l}\text { Acquisition } \\
\text { Date }\end{array}$ & $\begin{array}{l}\text { Spatial } \\
\text { Resolution }\end{array}$ & Path and Row & $\begin{array}{l}\text { Data } \\
\text { Source }\end{array}$ \\
\hline Landsat TM & $1984 / 12 / 18$ & $30 \mathrm{M}$ & $191 / 54,55$ & USGS \\
\hline Landsat TM & $1990 / 12 / 27$ & $30 \mathrm{M}$ & $191 / 54,55$ & USGS \\
\hline $\begin{array}{l}\text { Landsat } \\
\text { ETM+ }\end{array}$ & $2002 / 11 / 18$ & $30 \mathrm{M}$ & $191 / 54,55$ & USGS \\
\hline $\begin{array}{l}\text { Landsat } \\
\text { ETM+ }\end{array}$ & $2014 / 03 / 05$ & $30 \mathrm{M}$ & $191 / 54,55$ & USGS \\
\hline $\begin{array}{l}\text { Topographic } \\
\text { maps }\end{array}$ & 1963 & Scale 1:50,000 & ------- & F.S.S. Oyo \\
\hline
\end{tabular}

These maps show a clear pattern of increased urban expansion of the town prolonging both from urban center to adjoining non-built up areas along major transportation corridors.

The highest rate of urban growth is observed during the third period of urbanization (2002 to 2014) in which the built up area increased more than twice $11.3617587 \%$ within 12 years as
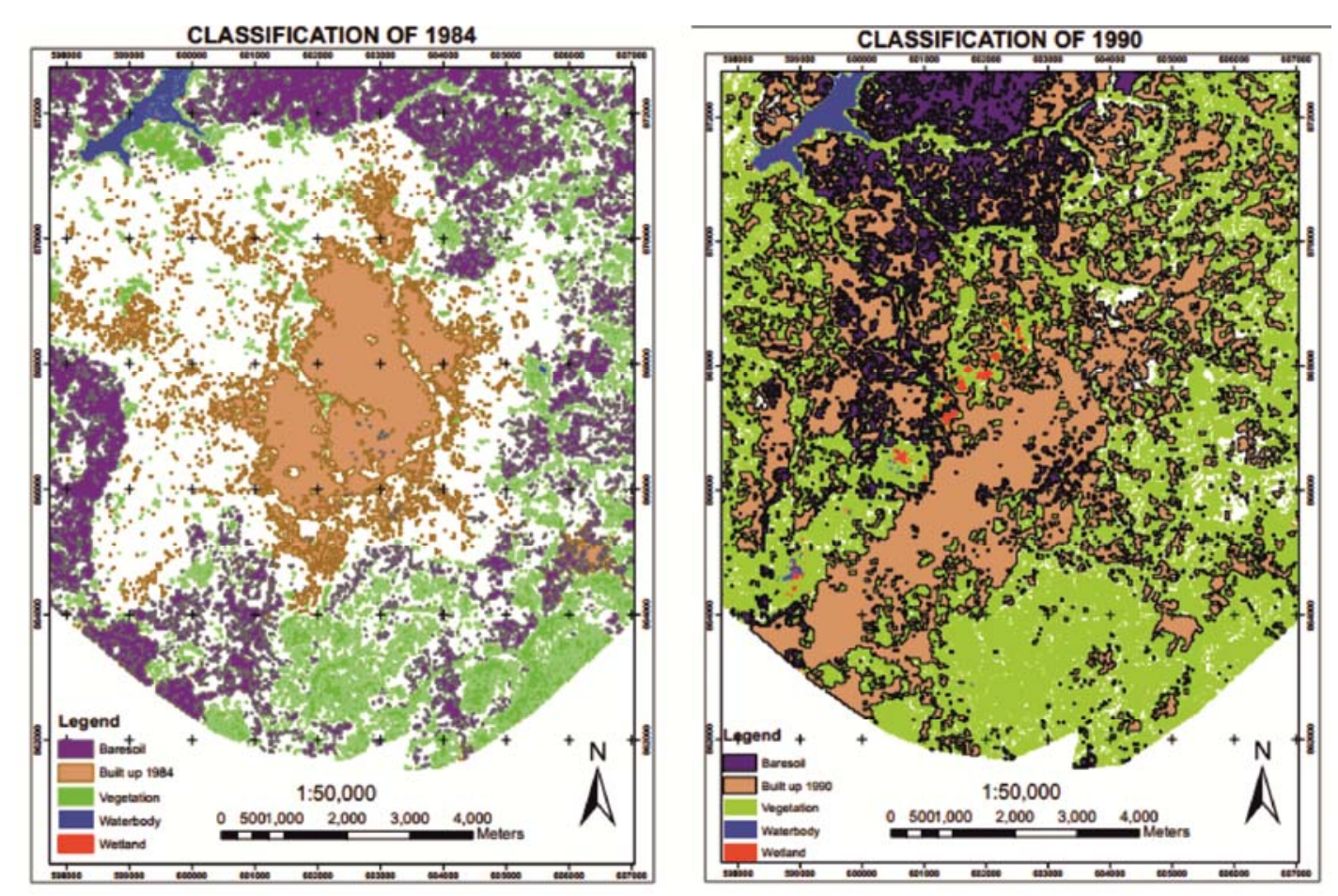

Figure 3: Classified Map of the Study area (Oyo Town) for the year 1984 and 1990 shown in Table 3. This is followed by $5.0614504 \%$ and $3.9244226 \%$ during the second (1990 to 2002) and the third (1984 to 1990) period of urbanization respectively. This indicates more rapid urbanization has been taking place in the study area during the period of 2002 to 2014 compared to the two other periods.

\footnotetext{
Figure 3: Classified Map of the Study area (Oyo Town) for the year 1984 and 1990
} 
It could be as a result of improvement in economy or since Oyo town is basically dominated by civil servant during this period there was wages increases both from Federal
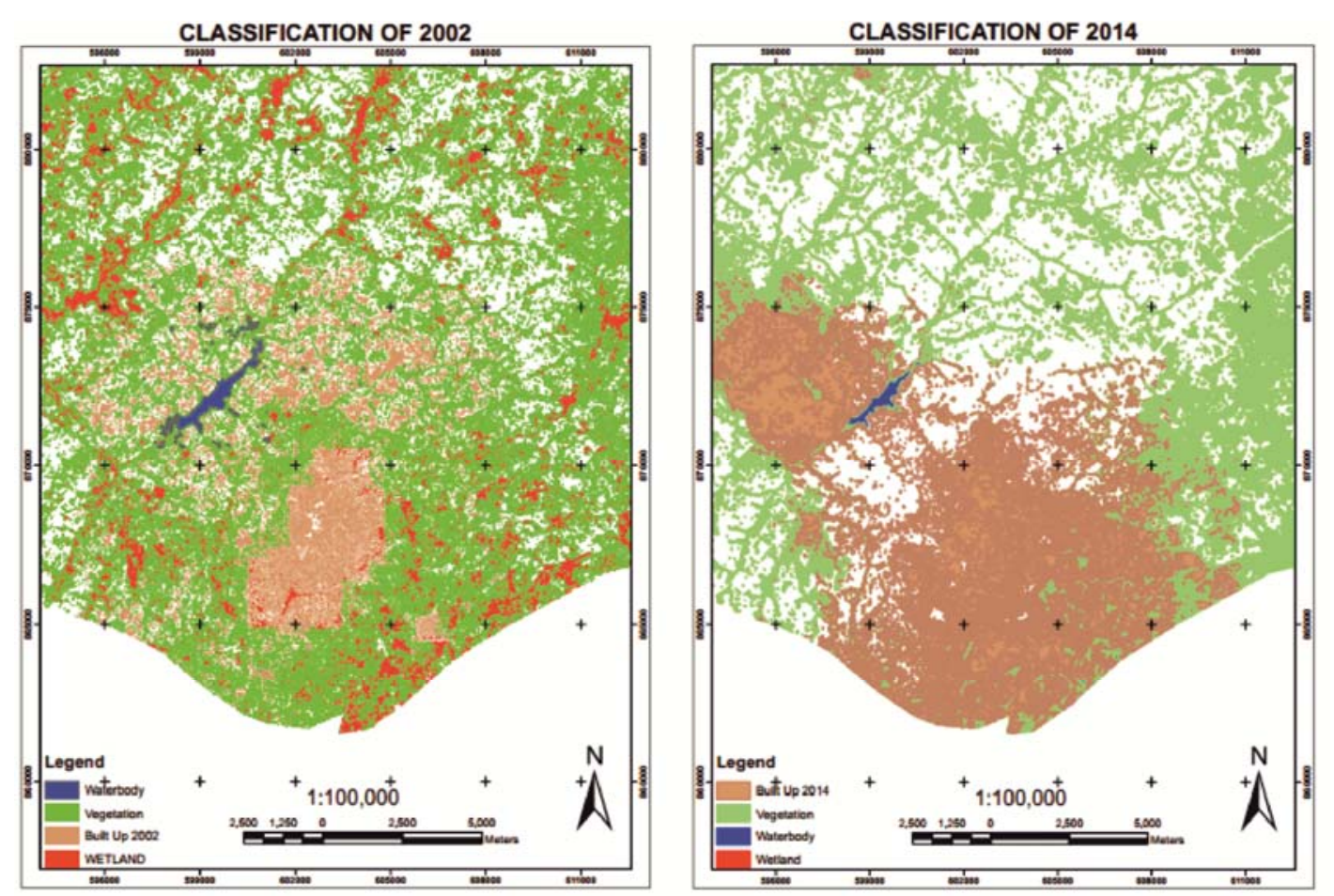

Figure 4: Classified map of study area(Oyo Town) for the year 2002 and 2014

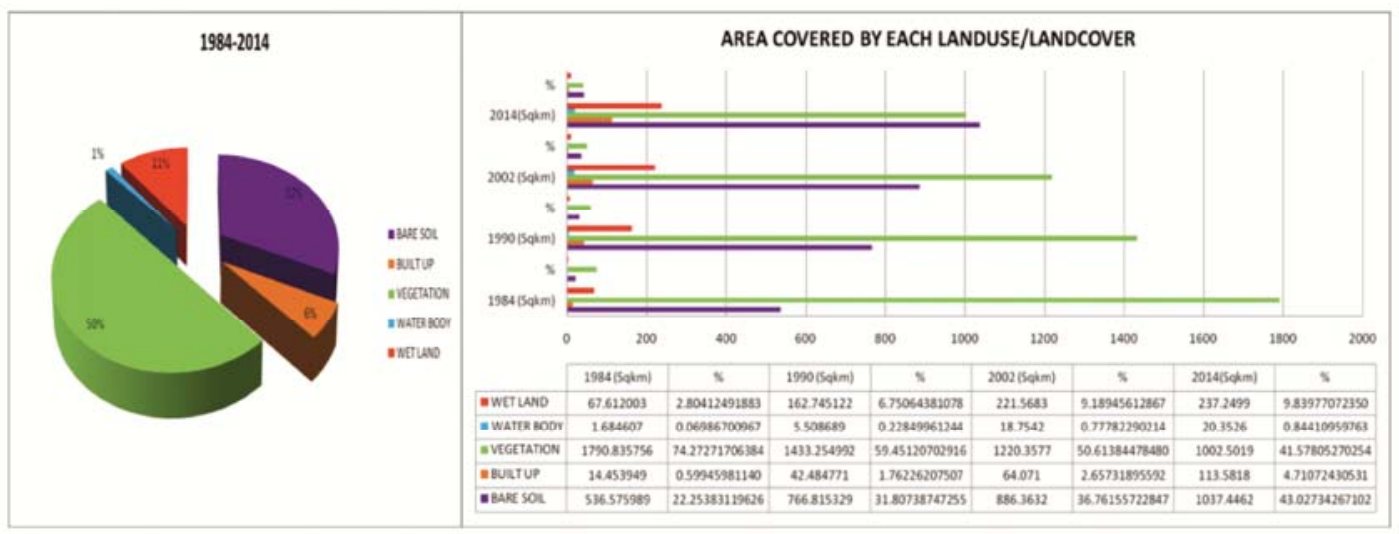

Figure 5: Pie chart and Histogram showing areas change occurred in 1984 and 2014

\section{Urbanization Dynamism in Oyo Town}

Having classified all imageries of 1984, 1990, 2002 and 2014 built-up area of the town, the four thematic layers were then overlaid on each other. Figure 6 and Figure 7 show the and States government to the civil servant which actually increase their take home and personal savings of workers. 
last few decades exceeding the pace at which urban services and housing are provided. Also, due to these factors, the expansion of Oyo town is steadily advancing at a fast pace leading to engulfing of adjacent rural landscape and urban centers.

Table 2: Urban Change Trend

\begin{tabular}{|c|c|c|c|c|c|c|c|c|}
\hline $\begin{array}{l}\text { LAND } \\
\text { USE/COVER }\end{array}$ & $\begin{array}{l}1984 \\
\text { (SQ.KM) }\end{array}$ & $\%$ & $\begin{array}{l}1990 \\
\text { (SQ.KM) }\end{array}$ & $\%$ & $\begin{array}{l}2002 \\
\text { (SQ.KM) }\end{array}$ & $\%$ & $\begin{array}{l}2014 \\
\text { (SQ.KM }\end{array}$ & $\%$ \\
\hline Bare soil & 536.575989 & \begin{tabular}{|l|}
22.25383119626 \\
\end{tabular} & 766.815329 & \begin{tabular}{|l|}
31.80738747255 \\
\end{tabular} & 886.3632 & 36.76155722847 & 1037.4462 & \begin{tabular}{|l}
43.02734267102 \\
\end{tabular} \\
\hline Built- up & 14.453949 & 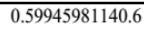 & 42.484771 & \begin{tabular}{|l|}
1.762262075071 .8 \\
\end{tabular} & 64.071 & 2.657318955922 .7 & 113.5818 & 4.710724305314 .7 \\
\hline Vegetation & 1790.835756 & $\begin{array}{l}74.2727170 \\
\end{array}$ & 1433.254992 & 59.45120702916 & 1220.3577 & 50.6138447848 & 1002.5019 & 41.57805270 \\
\hline Water body & 1.684607 & 0.06986700967 & 5.508689 & 0.22849961244 & 18.7542 & 0.77782290214 & 20.3526 & \begin{tabular}{|l|}
0.84410959763 \\
\end{tabular} \\
\hline Wet land & 67.612003 & 2.80412491883 & 162.745122 & 6.75064381078 & 221.5683 & 9.18945612867 & 237.2499 & 9.8397707235 \\
\hline total & 2411.162304 & 100.00 & 2410.808903 & 100.00 & 2411.1144 & 100.00 & 2411.1324 & 100.00 \\
\hline
\end{tabular}

Table 3: Analysis of Built up area Expansion on Total Area

\begin{tabular}{|l|l|l|l|l|l|}
\hline Study period & Change (sq.km) & Change (\%) & Time span & Growth & Average \\
& & & & & \\
\hline $1984-1990$ & 28.04 & 3.9244226 & 6 years & 0.7 & \\
\hline $1990-2002$ & 21.58 & 5.0614504 & 12 years & 0.4 & 0.7 \\
\hline $2002-2014$ & 49.51 & 11.3617587 & 12 years & 0.9 & \\
\hline
\end{tabular}

\section{Conclusions}

From the overview of the research work, it has been possible to successfully assess the changes that have taken place in the urban expansion pattern both at the center and at associated settlements. At the center, the town has experienced fragmented urban expansion process particularly at the fringe areas with substantial built-up increase while the center underwent relatively compact growth by infilling open spaces and through edge expansion overtime. Oyo town is undergoing outlying or leap-frog expansion. Outlying or leap-frog expansion is a change from nondeveloped to developed land cover occurring beyond existing developed areas. Leap-frog development is also referred to as urban sprawl as the expansion of urban area is in a way that demands the extension of public facilities.It was deduced from the imageries analysis that for the past thirty years, $1984-2014$, Oyo town has been undergoing extensive land cover change. The classification of multi-temporal satellite images of four different time periods i.e. 1984, 1990, 2002 and 2014 into built-up and non-built up land cover classes has resulted into a highly simplified and abstract representation of the study area. These maps show a clear pattern of increased urban expansion prolonging both from urban center to adjoining non-built up areas in all directions alongside major transportation corridors. The synoptic analysis of spatio-temporal land cover change revealed that urbanization has significantly transformed the urban landscape 
of Oyo town. The built up area in the town has expanded from $14.453949 \mathrm{~km} 2$ in 1984 to $113.5818 \mathrm{~km} 2$ in 2014 study period.

In total, $99.127851 \mathrm{~km} 2$ of non-built up area has been converted to urban area. This research work has successfully being carried out and analyzed to quantified the extent, rate and directions of spatio temporal urban expansion in the study area. The results presented in this study shows that remote sensing satellite images and geographic information system are valuable tool for the analysis and extraction of information on urban expansion patterns at different spatial scale and they can offer a comprehensive opportunity for the description of process, and facilitate interurban comparison.

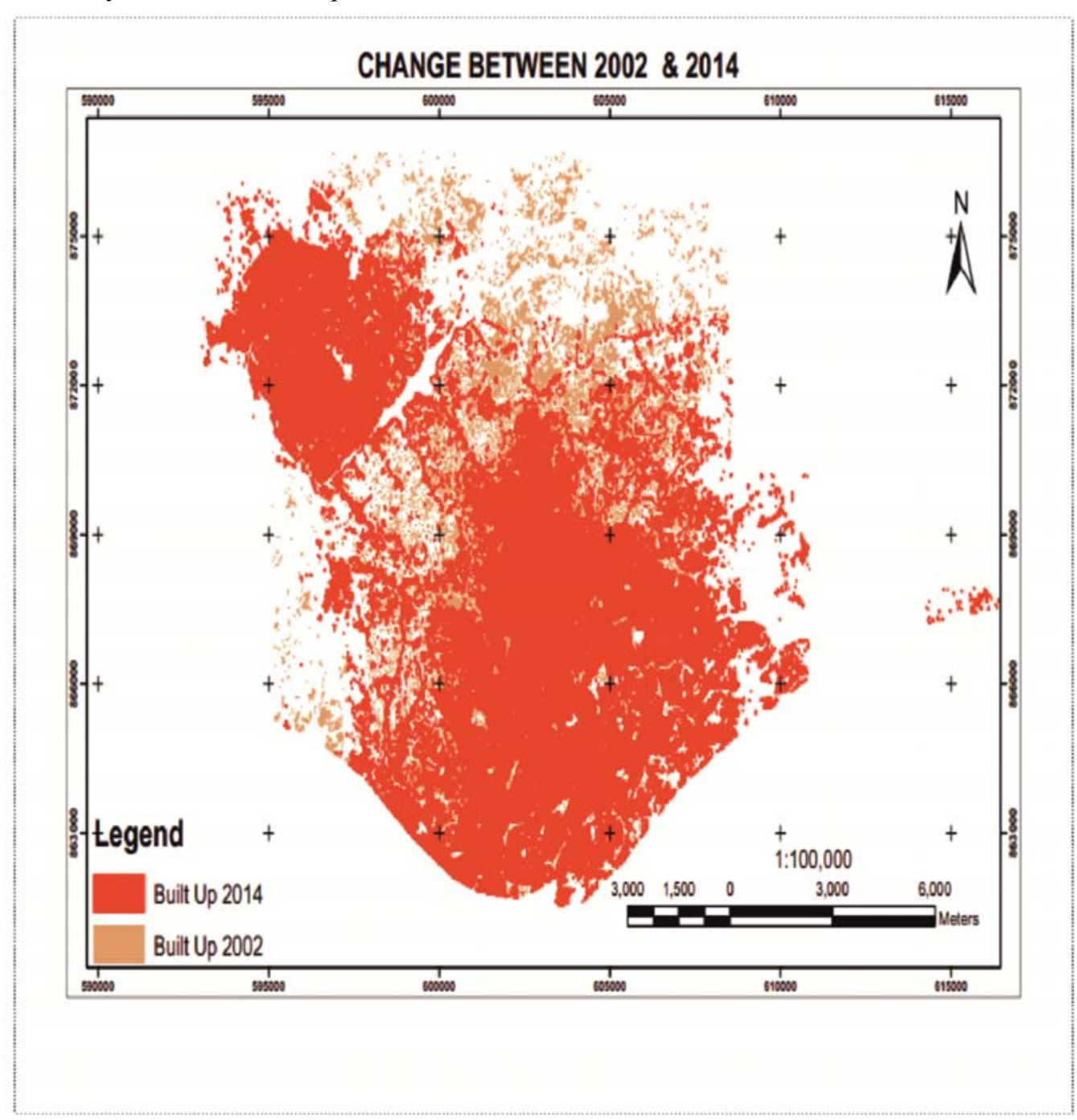

Figure 6. Map overlay of 2002 and 2014 urbanization extent 


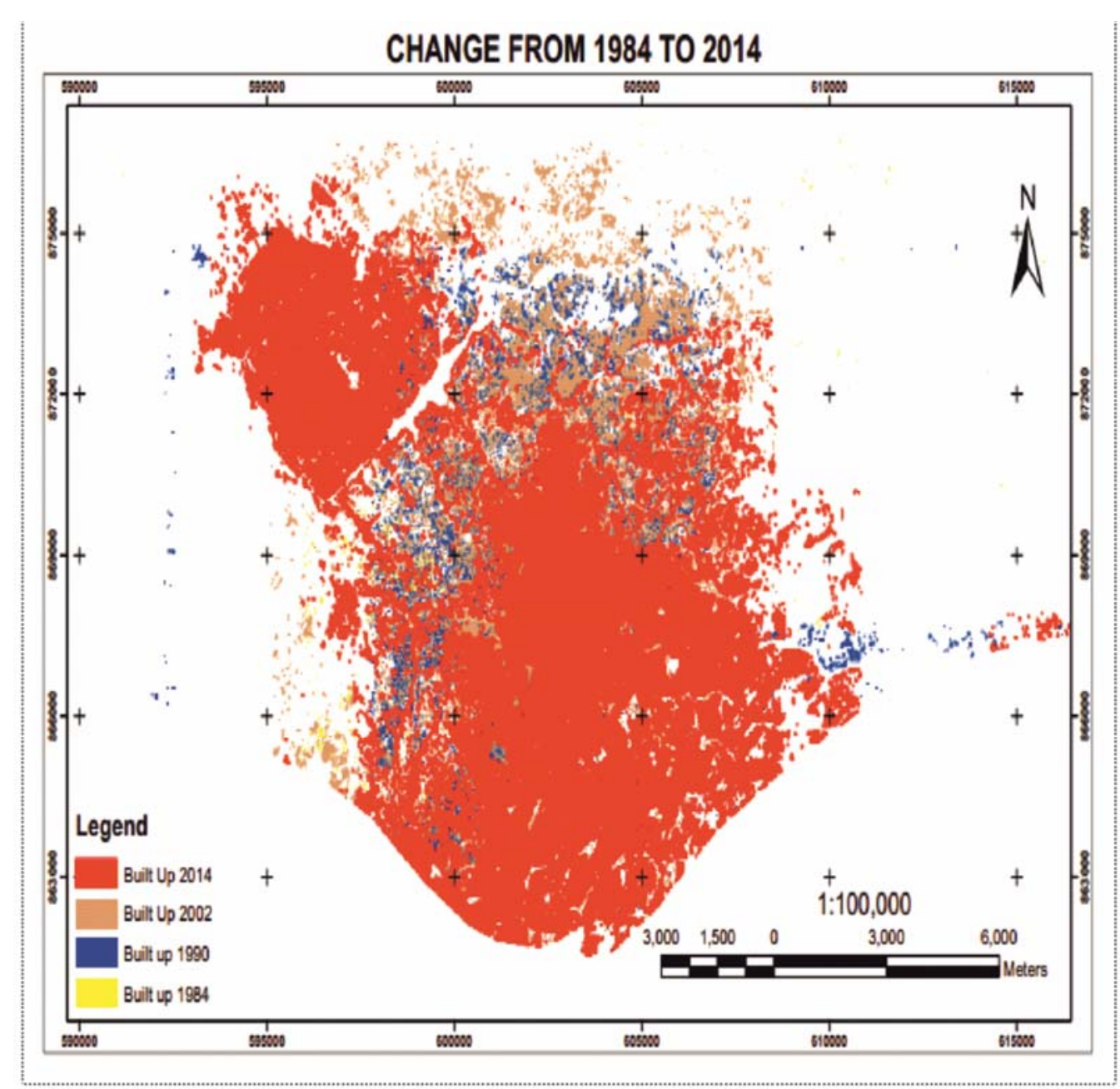

Figure 7: Map overlay of 1984 - 2014 urbanization extent

\section{Acknowledgements}

The Authors uses this medium to acknowledge the contribution and effort of Dr. D.N. Olayinka of Surveying and Geoinformatics Department, Faculty of Engineering, University Of Lagos, Akoka, Lagos State, Nigeria and also Federal School of Surveying, Oyo, Oyo State, Nigeria for their contributions.

\section{References}

Allen, J. and Lu, K. (2003): Modeling and Prediction of Future Urban Growth in the Charleston Region of South Carolina: a GIS- based Integrated Approach.

Bhatta, B. (2009): Analysis of urban growth pattern using remote sensing and GIS: a case study of Kolkata, India. International Journal of Remote Sensing, 30(18), 47334746.

Brito, P. L. and Quintanilha, J.A. (2012): A Literature Review, 2001-2008, of classification methods and inner urban characteristics identified in multispectral remote sensing images. Paper presented at the proceedings of the 4th GEOBIA, Rio de Janeiro - Brazil.

Burak, S., Doğan, E. and Gazioğlu, C. (2004). Impact of urbanization and tourism on coastal environment. Ocean and Coastal Management 47(9-10): 515-527.

Dihkan, M., Güneroğlu, N., Güneroğlu, A. and Karsl1, F. (2017). The need for ecosystembased coastal planning in Trabzon city, IJEGEO, Vol.4(3): 193-205. 
Ding, H., Wang, R.-C., Wu, J.-P., Zhou, B., Shi, Z. and Ding, L.-X. (2007): Quantifying Land Use Change in Zhejiang Coastal Region, China Using Multi-Temporal Landsat TM/ETM+ Images. Pedosphere, 17(6), 712-720. doi:10.1016/s10020160(07) 60086-1

Ezeigbo,C.U (Eds),(1998): Principle and Applications of Geographic Information Systems (series in Surveying and Geoinformatics) Department of Surveying and Geoinformatics, Faculty of Engineering, University of Lagos. Panaf Press, Lagos, Nigeria, pp90-104.

Guindon,B. and Zhang,Y(2009): Automated Urban Delineation from Landsat Imagery based on Spatial Information Processing, Photogrammetric Engineering \& Remote Sensing, 75(7),845-858.

Huang, B., Zhang, L. and Wu, B. (2009): Spatiotemporal analysis of rural-urban land conversion. International Journal of Geographical Information Science, 23(3), 379-398. doi: 10.1080/13658810802119685

Islam,K., Jashimuddin, M.,.Nath, b., and Nath, K. (2016). Quantitative assessment of land cover change using landsat time series data: case of Chunati Wildlife Sanctuary (CWS), Bangladesh, IJEGEO, Vol. 3(2): 45-55

Osgouei, P. E. and Kaya, S. (2017). Analysis of land cover/use changes using Landsat 5 TM data and indices. Environmental Monitoring and Assessment, 189(4): 136-147.

Roberts, D. A. and Herold, M. (2004).Imaging spectrometry of urban materials, in King, P., Ramsey, M.S. and G. Swayze, (eds.), Infrared Spectroscopy in Geochemistry, Exploration and Remote Sensing, Mineral Association of Canada, Short Course Series., 33, 155-181.

Subair, A.O. (2006): Change detection in land use and land cover using remote sensing data and GIS( a case study of Ilorin and its environs in Kwara state).Department of of Geography, University of Ibadan, Oyo state, Nigeria

UN (1999) .Africa a world of cities, UN World Urbanization Prospects.

UN-Habitat (2008). Cities and Climate Adaptation. Seville, Spain.

UN-Habitat (2009). The State of African Cities 2008: A Framework for Addressing Urban Challenges in Africa: Renouf Publishing Company Limited.
UN-Habitat (2012). Cities and Climate Change: Global report on human settlements, 2011/United Nations Human settlements programme.

Zhou.,X.. and Wang,Y.C.(2011).Spatialtemporal dynamics of urban green space in response to rapid urbanization and greening policies. Landscape and urban planning, 100(3): 268-277. 